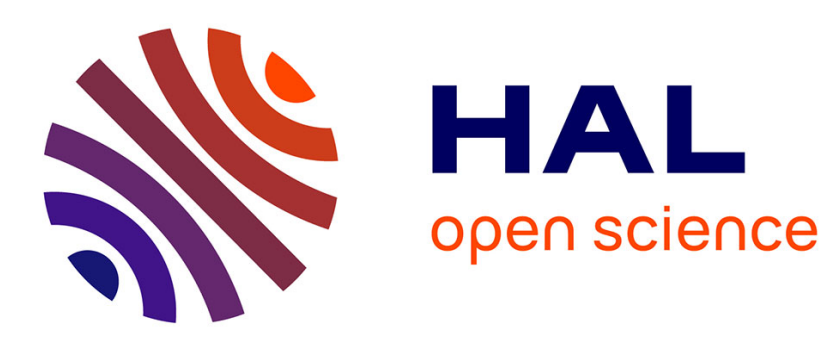

\title{
No serological evidence for Borrelia burgdorferi sensu lato infection in patients with dilated cardiomyopathy in Northern France
}

Yohan N'guyen, François Lesaffre, Damien Metz, Sylvie de Martino, Benoit Jaulhac, Laurent Andréoletti

\section{To cite this version:}

Yohan N'guyen, François Lesaffre, Damien Metz, Sylvie de Martino, Benoit Jaulhac, et al.. No serological evidence for Borrelia burgdorferi sensu lato infection in patients with dilated cardiomyopathy in Northern France. Infectious diseases (London, England), 2016, 48 (10), pp.763-764. 10.1080/23744235.2016.1193790 . hal-03267179

\section{HAL Id: hal-03267179 \\ https://hal.science/hal-03267179}

Submitted on 28 Jun 2021

HAL is a multi-disciplinary open access archive for the deposit and dissemination of scientific research documents, whether they are published or not. The documents may come from teaching and research institutions in France or abroad, or from public or private research centers.
L'archive ouverte pluridisciplinaire HAL, est destinée au dépôt et à la diffusion de documents scientifiques de niveau recherche, publiés ou non, émanant des établissements d'enseignement et de recherche français ou étrangers, des laboratoires publics ou privés. 


\section{Letter to the editor}

\section{Infectious Diseases SINF-2016-0191 R1}

\section{"No serological evidence for Borrelia burgdorferi sensu lato infection in patients with Dilated Cardiomyopathy in Northern France"}

$$
\text { (763 words) }
$$

Running title: No association between Borrelia \& DCM.

Yohan N'Guyen ${ }^{1,2 *}$, François Lesaffre ${ }^{2,3}$, Damien Metz ${ }^{2,3}$, Sylvie De Martino ${ }^{4}$, Benoit Jaulhac $^{4}$, Laurent Andréoletti ${ }^{1,2}$.

${ }^{1}$ Laboratoire de Virologie médicale et moléculaire, Centre hospitalier universitaire de Reims, France.

${ }^{2}$ EA-4684 Cardiovir, Faculté de médecine, Université de Reims Champagne-Ardenne, Reims, France.

${ }^{3}$ Service de Cardiologie, Centre hospitalier universitaire de Reims, France.

${ }^{4}$ Laboratoire de bactériologie, Hôpitaux universitaires de Strasbourg, France.

*corresponding author: Laboratoire de Virologie médicale et moléculaire, Centre hospitalier universitaire de Reims, Avenue du Général Koenig, 51100 Reims. Tel (+33)326789422 Fax (+33)326784090 mail: yohan.nguyen@wanadoo.fr

Disclosure Statement: No competing financial interests exist. 


\section{Keywords:}

Dilated Cardiomyopathy; Borrelia burgdoferi sensu lato; serology; ceftriaxone;

Endomyocardial Biopsy. 
Dear Editor,

We read with interest a recent review article in the present journal in which evidence in favor of Borrelia burgdorferi as an etiological agent of vasculitis and stroke was presented [1]. A more controversial issue seems to be the possible role of Borrelia burgdorferi sensu lato (BBSL) in the development of Dilated Cardiomyopathy (DCM) [2-5]. The pathophysiological process leading to DCM is presumed to be due to the persistence of BBSL in myocardium of infected patients after an episode of myocarditis leading to the production of anti endothelial or/and anti heart antibodies and therefore to the development of an apparently "idiopathic” DCM (iDCM) [4]. The arguments for such process were: BBSL positive serology, BBSL detection in Endomyocardial biopsies (EMBs) using microscopy or Polymerase Chain reaction (PCR) assays and improvement of patient's cardiac condition after treatment by ceftriaxone [6].

However, at the opposite end of cardiac conduction abnormalities [7], the response to such antibiotic treatment was not present in all iDCM patients suggesting an absence of active BBSL infection despite positive serological and/or molecular detection assays [6]. Moreover, systematic treatment of iDCM patients could not be considered in clinical practice because exposure to ceftriaxone may lead to acquiring extended-spectrum $\beta$-lactamase-producing gram-negative rods that are now one of the main health concerns worldwide. Taking into account all these elements, physicians in care of iDCM patients shall try to predict which patient may benefit from an antibiotic treatment by ceftriaxone only with the help of clinical context and biological investigations. This point remains difficult in clinical practice because previously reported cases [2-4] were based on direct bacteriological examination, culture or PCR assays on EMBs, whose indications are limited in clinical practice, according to the current American Heart Association (AHA) and European Society of Cardiology (ESC) recommendations [8]. 
Because serological screening remains the sole non invasive test in this setting, we performed a BBSL serological screening of IgG and IgM using ELISA Enzygnost borreliosis Vlse, $\left(\right.$ Siemens $\left.{ }^{\circledR}\right)$ in the serum or plasma of 15 patients suffering from iDCM and followed regularly in Reims university hospital. All of these patients were living in North-eastern France where Lyme borreliosis is endemic [9]. Endomyocardial Biopsies (EMBs) had been prospectively performed in 10 out of the 15 study iDCM patients, according to AHA and ESC recommendations [8]. All sera with positive or borderline BBSL antibody results were tested by western Blot analysis (Borreliosis reference centre's in house immunoblot assay using Borrelia garinii IB6 antigens). Western Blot analysis was interpreted as positive in case of reactivity to more than 4 BBSL antigens. EMBs were also routinely screened by PCR for the presence of common cardiotropic viruses (Enterovirus, Parvovirus B19, Human Herpes Virus) using Argene Biomerieux ${ }^{\circledR}$ commercial kits, according to manufacturer's instructions. Clinical data were extracted from medical records. The Hospital Ethics Committee approved the study, and informed consent had previously been obtained from each of the patients.

Results are depicted in the table I. BBSL seroprevalence reported in our study's population was zero [Confidence Interval 95\%: - 0.07 to 0.19 ]; excluding the implication of BBSL in the development of DCM in any of our 15 study patients that were all living in Northern France. Therefore, we did not perform BBSL detection by PCR assays in available EMBs, because (i) Negative Predictive Value of negative BBSL serology at the late stage of the disease is considered to be higher than 99\% [10], especially as BBSL serology is considered as positive only in presence of positive ELISA and confirmed in western Blot analysis (ii) outer surface protein A gene PCR gave non specific results in case of simultaneous detection of Human Herpes Virus 6 or Parvovirus B19 genomes in cardiac tissues [4]; which occurred frequently in EMBs samples (table I). 
Despite the low number of tested cases, the non-existent BBSL seroprevalence reported here, advocates against the potential etiological role of BBSL in the development of unexplained DCM and against the systematic use of ceftriaxone in idiopathic DCM patients in Northern France. The use of ceftriaxone should only be limited to: (i) DCM patients whose diagnosis of late Lyme borreliosis has been established as probable by a systematic approach taking into account previous medical history including exposure to tick bites, complete clinical examination associated with BBSL fully positive serology and with the absence of all other etiological causes of DCM; (ii) DCM patients living in BBSL endemic area with a BBSL positive serology and requiring an heart graft. In this latter situation, treatment by ceftriaxone could be initiated before heart transplantation and definitive confirmation of diagnosis using reference PCR assays on explanted heart tissues. 


\section{Acknowledgements:}

This work was supported by a clinical research grant from the Reims University Medical Centre (grant EA4684-CardioVir).

\section{References:}

[1]. Zajkowska J, Garkowski A, Moniuszko A, Czupryna P, Ptaszyńska-Sarosiek I, et al. Vasculitis and stroke due to Lyme neuroborreliosis - a review. Infect Dis (Lond). 2015;47:16.

[2]. Stanek G, Klein J, Bittner R, Glogar D. Isolation of Borrelia burgdorferi from the myocardium of a patient with longstanding cardiomyopathy. N Engl J Med. 1990;322:249-52.

[3]. de Koning J, Hoogkamp-Korstanje JA, van der Linde MR, Crijns HJ. Demonstration of spirochetes in cardiac biopsies of patients with Lyme disease. J Infect Dis. 1989;160:150-3.

[4]. Kubánek M, Šramko M, Berenová D et al. Detection of Borrelia burgdorferi sensu lato in endomyocardial biopsy specimens in individuals with recent-onset dilated cardiomyopathy. Eur J Heart Fail. 2012;14:588-96.

[5]. Suedkamp M, Lissel C, Eiffert H et al. Cardiac myocytes of hearts from patients with end-stage dilated cardiomyopathy do not contain Borrelia burgdorferi DNA. Am Heart J. 1999;138:269-72.

[6]. Gasser R, Fruhwald F, Schumacher M et al. Reversal of Borrelia burgdorferi associated dilated cardiomyopathy by antibiotic treatment? Cardiovasc Drugs Ther. 1996;10:351-60

[7]. Khalil S, Padala SK, Hui CM, Steckman DA, Sidhu MS, Torosoff MT. Lyme Carditis in the Fast Lane: From Alternating Bundle Branch Block to Asystole in 12 Hours. Conn Med. 2015;79:517-20. 
[8]. Cooper LT, Baughman KL, Feldman AM et al. The role of endomyocardial biopsy in the management of cardiovascular disease: a scientific statement from the American Heart Association, the American College of Cardiology, and the European Society of Cardiology. Endorsed by the Heart Failure Society of America and the Heart Failure Association of the European Society of Cardiology. J Am Coll Cardiol. 2007; 50:1914-31.

[9]. Vandenesch A, Turbelin C, Couturier E et al. Incidence and hospitalisation rates of Lyme borreliosis, France, 2004 to 2012. Euro Surveill. 2014;19. pii: 20883

[10]. Stanek G, Fingerle V, Hunfeld KP et al .Lyme borreliosis: clinical case definitions for diagnosis and management in Europe. Clin Microbiol Infect. 2011;17:69-79. 